\title{
DISCOVERING THE FACTORS INFLUENCING STUDENTS' PERCEPTION OF THE EDUCATIONAL ENVIRONMENT IN THE CONTEXT OF FOREIGN LANGUAGE TRAINING IN A TECHNICAL HIGHER SCHOOL
}

\begin{abstract}
SUMMARY
Introduction. One of the most challenging tasks for educators is to encourage students of a nonlinguistic institute to study languages. Traditionally, such institutions focus more on promoting the learning of special subjects. However, in the knowledge-based economy, multidisciplinary skills are of fundamental importance. To encourage language learning education managers provide the learning process participants with motivating educational environment.

The Aim of the Study. To report the findings of the pilot study, which explores how students perceive different aspects of the educational environment in the context of language teaching and learning in a technical higher school.

Materials and Methods. This paper aims to focus on a few essential factors that might have a significant impact on student motivation for studying languages. Information was gathered through the use of the student survey conducted in Transport and Telecommunication Institute; it was based on the structured questionnaire containing a few perception items in relation to foreign language training in a higher technical school.

Results and Conclusions. In general, the results of the study show that the students assess all educational environment aspects identified in the survey as having a significant impact on language teaching and learning in a technical higher school. The results basically would imply that the factors students regard as the most important for supporting their studies in relation to language teaching and learning are those, which they directly associate with learning a language. Keywords: language teaching and learning, educational environment, student feedback, evaluation indicators
\end{abstract}

\section{INTRODUCTION}

Today, one of the key tasks for educators is to create more language-friendly environment in European higher education institutions (The Common European Framework of Reference for Languages: Learning, Teaching, Assessment, 2001). It is necessary for promoting language teaching and learning, which is vital for providing mutual understanding, stimulating mobility across Europe, and ensuring better access to various information sources.

One of the most challenging tasks for educators is to encourage students of a non-linguistic institute to study languages. Traditionally, such institutions focus more on promoting the learning of special subjects. However, the international job market needs multidisciplinary skills including good language skills. In the knowledge-based economy, multidisciplinary skills are of fundamental importance. To encourage language learning education managers have to provide the learning process participants with motivating educational environment. We assume that among other things having their impact on the educational environment efficiency, an essential factor is how well it is assessed by the learning process participants and to what extent it motivates students for further studies By analyzing the factors that influence students' perception of the educational environment we will be able to create a constructive educational environment conducive to of language learning and teaching. 


\section{THE AIM OF THE STUDY}

The purpose of this paper is to report the findings of the pilot study, which explores how students perceive different aspects of the educational environment in the context of language teaching and learning in a higher technical school.

\section{MATERIALS AND METHODS}

This paper aims to focus on a few essential factors that might have a significant impact on student motivation for studying languages. Information was gathered through the use of the student survey conducted in Transport and Telecommunication Institute that was based on the structured questionnaire containing a few perception items in relation to foreign language training in a higher technical school.

\section{Methodology}

To determine the basic educational environment aspects that might influence students' perception of the environment we performed a pilot study. We have used qualitative methods that are widely utilized in education, and which are gaining increasing popularity in management research (Cassel, Symon, 2006; Johnson et al., 2007). The qualitative research model focuses on people's direct experience (Cropley, 2002). Using qualitative methods would give us a good opportunity to investigate diverse aspects of the educational environment from different perspectives; it would help us consider the educational environment as an integrated system.

We consider collecting student feedback - students' perceptions of the educational environment - as part of the managerial process called the educational environment evaluation. Carrying out the educational environment evaluation we are interested in discovering how our students assess the environment in terms of the support provided, as material as non-material. This way, students describe their learning experience and express their wishes and expectations. We presume that the learner-centred environment evaluation model, which takes into account students' perspective about the quality of the educational environment, may be rather helpful. We also think that our attention should be focused on the students' requirements defined in terms of a) content - what to learn (information, skills and competences, etc.); b) opportunities - how to learn (facilities, technological support, psychological climate, etc.)

We have developed a questionnaire (see Table 1) including the four key factors that are associated with the four basic educational environment aspects, and are supposed to influence students' perceptions in relation to of foreign language training in a technical higher school. The purpose of this study was to verify if students consider the educational environment aspects specified in the questionnaire as essential factors that might have a significant impact on their studies.

The questionnaire was distributed among students enrolled in the ESP (English for Specific Purposes) course. Data collection for the present study took place at the beginning of the $2^{\text {nd }}$ semester, 2007/2008 academic year. The type of sampling was clustered according to the Faculty of Management and Economics and the Faculty of Electronics and Computer Science such that the students selected were distributed representatively from both faculties. The rationale for selecting students was to obtain a constituent and comprehensive perspective from within the Institute. The research population in the sample included 210 Day Department students taking their ESP course in Transport and Telecommunication Institute.

We received responses from 201 respondents. In all, from 201 students voluntary participated in the survey, 141 were students of the Faculty of Management and Economics, and 60 were students of the Faculty Electronics and Computer Science. The mean age of the students was 19 years. 
Table 1. Questionnaire used to rate the significance of the educational environment aspects in relation to foreign language training in a technical higher school

\begin{tabular}{|l|l|l|l|}
\hline \multicolumn{4}{|c|}{ Fow important are the following factors for foreign languages training? } \\
\hline \multicolumn{1}{|c|}{} & Essential & $\begin{array}{c}\text { I don't } \\
\text { know }\end{array}$ & $\begin{array}{c}\text { Non- } \\
\text { essential }\end{array}$ \\
\hline I. The executive environment (learning process organization) & & \\
\hline 1) Quality of acquired skills and competences & & & \\
\hline 2) Quality and availability of the given information & & & \\
\hline 3) Quality of conducted lessons & & & \\
\hline II. Physical and technological environment & & \\
\hline 4) Quality of the laboratory equipment & & & \\
\hline 5) Lecture rooms and lecture halls amenities & & \\
\hline III. Instructional environment & & & \\
\hline 6) Academic programs and curricula content & & & \\
\hline 7) Teaching materials quality and availability & & & \\
\hline 8) Availability and quality of the Internet/intranet instructional \\
resources
\end{tabular}

We have developed a set of qualitative indicators related to the four basic educational environment aspects to be discussed and evaluated. These aspects embrace all material and nonmaterial resources of an educational organisation:

1. The executive environment (the learning process organisation);

2. The physical environment and technological environment (buildings, lecture rooms and lecture halls, facilities, laboratory equipment, computer-based information and communication systems);

3. The instructional environment (regulative documents, teaching materials);

4. The psychological environment (psychological climate in the organisation).

To assess the four basic aspects of the educational environment we used eleven qualitative indicators, which were included in the questionnaire as a number of items, and which had to be scored using a Likert-type scale:

Q1. Quality and availability of information;

Q2. Quality of acquired skills and competences;

Q3. Quality of conducted lessons;

Q4. Laboratory equipment facilities;

Q5. Lecture rooms and lecture halls amenities;

Q6. Study course content;

Q7. Teaching materials quality and availability;

Q8. Availability and quality of the Internet/intranet instructional resources;

Q9. Environment safety and comfort;

Q10. Collaboration with other students (possibility to work in a team);

Q11. Support from managers, teachers and attending staff. 
The evaluation indicators symbolize some qualitative attributes and represent the learning effects we expect to perceive from the language-friendly educational environment; they are either directly or indirectly associated with language teaching and learning, since the learning process is carried out as a complex multiform procedure.

Question formats are different; the most common being multiple-choice and openended questions (List, Web source: Audiencedialogue.net). We used multiple choice questions. The respondents anonymously rated each item as "Essential", "I don't know", or "Nonessential" in the context of learning a foreign language in a non-linguistic institute. Answering the question the question the interviewer ticked the appropriate box. We have also included an "other" category is to account for unexpected answers, which is also common for such question format (Ibid).

\section{Discussion}

The obtained data then were processed using SPSS software package. Table 2 and Table 3 show the percentage of students versus ratings: mean, standard deviation and variance.

Table 2. Percentage of students versus ratings

\begin{tabular}{|c|c|c|c|c|c|c|c|c|c|c|c|}
\hline \multicolumn{12}{|c|}{$\begin{array}{l}\text { Percentage of students who rated various factors associated with the educational environment as } \\
\text { essential (1), I don't know (2), or non-essential (3) }\end{array}$} \\
\hline Rating & $Q 1$ & $Q 2$ & $Q 3$ & $Q 4$ & $Q 5$ & Q6 & $Q^{7}$ & $Q 8$ & $Q^{9}$ & $Q 10$ & $Q 11$ \\
\hline Essential & 87.6 & 90 & 81.6 & 52.2 & 64.7 & 62.7 & 85.1 & 79.6 & 75.6 & 65.2 & 78.1 \\
\hline I don't know & 11.4 & 7.5 & 14.4 & 25.4 & 16.4 & 22.9 & 12.4 & 11.9 & 18.4 & 21.4 & 14.9 \\
\hline Non-essential & 1.0 & 2.5 & 4.0 & 22.4 & 18.9 & 14.4 & 2.5 & 8.5 & 6.0 & 13.4 & 7.0 \\
\hline
\end{tabular}

Table 3. Mean, standard deviation and variance

\begin{tabular}{|l|c|c|c|c|c|c|c|c|c|c|c|}
\hline Rating & Q1 & Q2 & Q3 & Q4 & Q5 & Q6 & Q7 & Q8 & Q9 & Q10 & Q11 \\
\hline Mean & 1.13 & 1.12 & 1.22 & 1.70 & 1.54 & 1.52 & 1.17 & 1.29 & 1.30 & 1.48 & 1.29 \\
\hline $\begin{array}{l}\text { Standard } \\
\text { deviation }\end{array}$ & .370 & .399 & .505 & .813 & .793 & .735 & .441 & .613 & .577 & .722 & .588 \\
\hline Variance & .137 & .159 & .255 & .660 & .629 & .541 & .195 & .376 & .332 & .521 & .346 \\
\hline
\end{tabular}

\section{RESULTS}

To summarize, the main results are as follows:

- Regarding [Q1], most students (87.6\%) agree that this aspect is essential for supporting the ESP course;

- Regarding [Q2], most students (90\%) agree that this aspect is essential for supporting the ESP course;

- Regarding [Q3], the majority of students (81.6\%) agree that this aspect is essential for supporting the ESP course;

- Regarding [Q4], 52.2\% of students agree that this aspect is essential for supporting the ESP course;

- Regarding [Q5], 64.7\% of students agree that this aspect is essential for supporting the ESP course;

- Regarding [Q6], 62.7\% of students agree that this aspect is essential for supporting the ESP course;

- Regarding [Q7], the majority of students (85.1\%) agree that this aspect is essential for supporting the ESP course;

- Regarding [Q8], most students (79.6\%) agree that this aspect is essential for supporting the ESP course; 
- Regarding [Q9], most students (75.6\%) agree that this aspect is essential for supporting the ESP course;

- Regarding [Q10], 65.2\% of students agree that this aspect is essential for supporting the ESP course;

- Regarding [Q+11], most students (78.1\%) agree that this aspect is essential for supporting the ESP course.

Performing a statistical analysis of the obtained results reveals that the majority of students perceive the educational environment aspects specified in the questionnaire as essential factors to helping them acquire a foreign language in a technical higher school, these aspects being related to

1. The executive environment: "quality of acquired skills and competences" (87.6\%), "quality and availability of the given information" (90\%), "quality of conducted lessons" $(81.6 \%)$.

2. The instructional environment: "teaching materials quality and availability" (85.1\%), "availability and quality of the Internet/intranet instructional resources" (79.6\%); though for the indicator "academic programs and curricula content" the percentage is lower $(62.7 \%)$.

3. The psychological environment: "environment safety and comfort" (75.6\%), "support from managers, teachers and attending staff (78.1\%); for the indicator "possibility to work in cooperation with other students" the percentage is lower $(62.7 \%)$.

4. The physical and technological environment, 52.2\% of students think that "quality of the laboratory equipment" is essential for supporting the ESP course; $62.7 \%$ of students think that "lecture rooms and lecture halls amenities" are vital for supporting the ESP course.

The hierarchy of the educational environment aspects related to language teaching and learning is presented below:

1. Quality and availability of the given information (90\%);

2. Quality of acquired skills and competences (87.6\%);

3. Teaching materials quality and availability $(85.1 \%)$;

4. Quality of conducted lessons $(81.6 \%)$;

5. Availability and quality of the Internet/intranet instructional resources $(79.6 \%)$;

6. Support from managers, teachers and attending staff (78.1\%);

7. Environment safety and comfort $(75.6 \%)$;

8. Academic programs and curricula content (62.7\%);

9. Possibility to work in cooperation with other students $(62.7 \%)$;

10. Lecture rooms and lecture halls amenities $(62.7 \%)$;

11. Quality of the laboratory equipment (52.2\%).

Picture 1 shows that the difference between students' answers is related to the following indicators:

- [Q4] - "Quality of the laboratory equipment";

- [Q5] - "Lecture rooms and lecture halls amenities";

- [Q6] - "Academic programs and curricula content";

- [Q10] - "Possibility to work in cooperation with other students". 


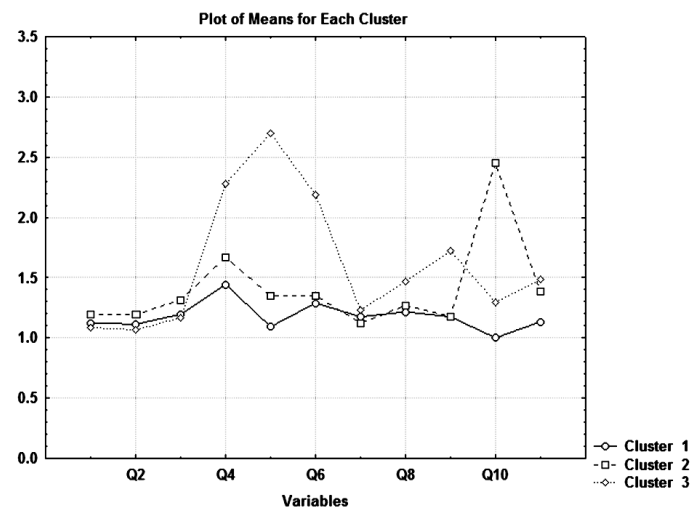

Picture 1. Distribution of respondents by
clusters: Comparison of student perception
of indicators $Q 4, Q 5, Q 6$, and $Q 10$

The divergence in the students' estimation of the significance of some factors in the context of language teaching and learning is rather big, especially with reference to indicator Q5 - "Lecture rooms and lecture halls amenities" and Q10 - "Possibility to work in cooperation with other students".

Among other factors that can have a positive influence on student perception of the educational environment, learners have also mentioned the following:

- "More extra-curriculum activities" (1 respondent);

- "More sport activities" (1 respondent);

- "More communication with teachers"(1 respondent);

- "More active participation in student exchange programmes" (4 respondents);

- "More active engagement in practical work" (7 respondents).

RESULTS AND CONCLUSIONS

The main findings of the pilot study are the following. Concerning student attitudes and perceptions of various educational environment aspects, the results basically would imply that the factors students regard as the most significant for supporting their studies in relation to language teaching and learning in a non-linguistic institute are those, which they directly associate with learning a language.

For a number of students, such aspects as the physical and technological environment are less associated with learning a language, lecture hall amenities and the laboratory equipment being essential for accordingly $62.7 \%$ and $52.2 \%$ of students. For them, learning a language is more connected not with the physical conditions the educational environment provide, but with direct interaction between learners, instructors, attending staff members and education managers. These results also indicate that teachers should involve Information and Communication Technologies (ICTs) in the learning process more actively, and encourage their students to use them more willingly. This is vital in the context of life-long learning and intensification of language learning in higher education institutions.

With respect to the instructional environment, the most significant effect on the student perception have those instructional materials, which students use directly in the learning process (teaching materials and the Internet/intranet resources). Academic programs and curricula content is perceived by students as a more abstract concept; so it is considered to be a less important factor that influences the learning procedures indirectly.

The indicator Q10 - "Possibility to work in cooperation with other students" - is assessed differently; we suppose that it may be explained by the phenomenon called the learning style - the way people learn, how they perceive and process information. According to the Felder \& Silverman (Web source: Learning: Styles, Strategies, Outcomes, 2006) learning style model, "students preferentially take in and process information in different ways: by seeing and hearing, reflecting and acting, reasoning logically and intuitively, analyzing and visualizing, steadily and in fits and starts". Thus, a student's individual learning style (Wright, 1987; Harmer, 2004) is associated with his/her individual behaviour and is related to his/her attitude to learning and knowledge implementation, the ability to work in a team in cooperation with other learners, and relationships with the teacher (instructor). 
In general, the results of the pilot study show that the students assess all educational environment aspects identified in the survey as having a significant impact on language teaching and learning in a technical higher school. We suppose that in their attempts to create a languagefriendly educational environment in a non-linguistic institute, education managers have to consider it as an integrated whole. They must establish and analyse the relationships between different educational environment aspects related to teaching and learning a language. If we consider the educational environment as an integrated system, which subsystems are interconnected and interrelated, we can better investigate this interaction to the greatest benefit of all learning process participants. This will allow us to utilize the resources that are at our disposal in the most efficient manner.

This paper has examined some but not all of the concerns associated with creating the language-friendly educational environment in a higher technical school. Our results suggest directions for further research. The next step of our research will be to work out a wide-ranging evaluation questionnaire, by means of which we can get student feedback in relation to the main educational environment aspects that have been discussed in the pilot study.

\section{REFERENCES}

1. Cassel, C. \& Symon, G. (2006) Taking Qualitative Methods in Organisation and Management Research Seriously. An International Journal Qualitative Research in Organizations and Management, Vol. 1, No. 1, p. 4-12.

2. Common European Framework of References for Languages (2001): available from http://www.coe.int/T/DG4/Portfolio/documents/Framework_EN.pdf (15.05.2009.)

3. Cropley, A. (2002) Qualitative Research Methods: An Introduction for Students of Psychology and Education. Rīga: Zinātne, 158 p.

4. Felder \& Silverman cited in: Learning: Styles, Strategies, \& Outcomes, 2006: available from http://hhh.gavilan.edu/jmaringer/learningstyles.html (26.10.2009.)

5. Harmer, J. (2004) The Practice of English Language Teaching. UK: Longman, p. 42-43.

6. Johnson, Ph., Buehring, A., Cassel, C., Symon, G. (2007) Defining Qualitative Management Research: an Empirical Investigation. An International Journal Qualitative Research in Organizations and Management, Vol. 2, No. 1, p. 23-42.

7. List, D. Know Your Audience: chapter 3, part A, Principles of questionnaires: available from http://www.audiencedialogue.net/kya3a.html; updated 22 May, 2002 (28.10.2009.)

8. Wright, T. (1987) Roles of Teachers and Learners. UK: Oxford University Press, p. 117-118.

\section{PhD student Yulia Stukalina}

University of Latvia, Faculty of Education and Psychology

Address: 74-76 Jurmalas gatve, Riga, LV-1083, Latvia

Mob. phone: +37126714382

E-mail: alina_s@tsi.lv 